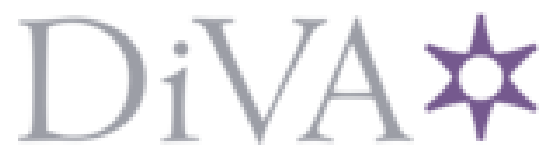

http://www.diva-portal.org

\title{
Postprint
}

This is the accepted version of a paper published in Journal of Clinical Nursing. This paper has been peer-reviewed but does not include the final publisher proof-corrections or journal pagination.

Citation for the original published paper (version of record):

Klaeson, K., Hovlin, L., Guvå, H., Kjellsdotter, A. (2017)

Sexual Health in Primary Healthcare: A Qualitative Study of Nurses' Experiences.

Journal of Clinical Nursing, 26(11-12): 1545-1554

https://doi.org/10.1111/jocn.13454

Access to the published version may require subscription.

N.B. When citing this work, cite the original published paper.

This is the peer reviewed version of the following article: Klaeson, K., Hovlin, L., Guvå, H. and Kjellsdotter, A. (2017), Sexual health in primary health care - a qualitative study of nurses' experiences. J Clin Nurs, 26: 1545-1554., which has been published in final form at http:// doi.org/10.1111/jocn.13454. This article may be used for non-commercial purposes in accordance with Wiley Terms and Conditions for Self-Archiving

Permanent link to this version:

http://urn.kb.se/resolve?urn=urn:nbn:se:his:diva-13201 
Received Date : 12-Jan-2016

Revised Date : 31-May-2016

Accepted Date : 11-Jun-2016

Article type : Original Article

\section{Sexual Health in Primary Healthcare - A Qualitative Study of Nurses' Experiences}

Kicki Klaeson PhD, RN, Senior Lecturer, School of Health and Education, University of

Skövde and Oncology Department, Skaraborgs hospital, Sweden

Phone: + 465004488000

E-mail: kicki.klaeson@his.se

Lina Hovlin RN, Home care, Skara Municipality 53231 Skara, Sweden

Phone: +46733865255

E-mail: linaemmesjo@hotmail.com

Hanna Guvå RN, Psychiatric Department, Skaraborgs hospital, Sweden

Phone: +46705382845

E:mail hanna.guva@gmail.com

Anna Kjellsdotter, PhD, RN, Senior Lecturer, School of Health and Education, University of

Skövde, Sweden

Phone + 46500448412

E:mail anna.johansson@his.se

Corresponding author:

\section{Kicki Klaeson}

Oncology Department, Skaraborgs hospital and University of Skövde, 54128 Skövde,

Sweden

This article has been accepted for publication and undergone full scientific peer review but has not been through the copyediting, typesetting, pagination and proofreading process which may lead to differences between this version and the Version of Record. Please cite this article as an 'Accepted Article', doi: 10.1111/jocn.13454 This article is protected by copyright. All rights reserved. 
Phone: + 465004488000

E-mail: kicki.klaeson@his.se

\section{Abstract}

Aim and objectives. To illuminate nurses' experiences and opportunities to discuss sexual health with patients in primary healthcare.

Background. Sexual health is a concept associated with many taboos and research shows that nurses feel uncomfortable talking to patients about sexual health and therefore avoid it. This avoidance forms a barrier between patient and nurse which prevents nurses from giving satisfactory healthcare to patients.

Design. A qualitative descriptive design.

Method. Semi-structured interviews were conducted with nine nurses in primary healthcare in Sweden. Data were analysed by using qualitative content analysis.

Results. During the analysis phase, five subcategories and two main categories were identified. The two main categories were: "Factors that influence nurses' opportunities to talk to patients about sexual health" and "Nurses' experiences of talking to patients about sexual health". Social norms in society were an obstacle for health professionals' opportunities to feel comfortable and act professionally. The nurses' personal attitude and knowledge were of great significance in determining if they brought up the topic of sexual health or not. The nurses found it easier to bring up the topic of sexual health with middle-aged men with for example diabetes. One reason for this is that they found it easier to talk to male patients. A further reason is the fact that they had received training in discussing matters of sexual health in relation to diabetes and other conditions affecting sexual health.

Conclusion. Nurses in primary care express the necessity of additional education and knowledge on the subject of sexual health. The healthcare organization must be reformed to put focus on sexual health.

Relevance for clinical practice. Guidelines for addressing the topic of sexual health must be implemented to establish conditions that will increase nurse's knowledge and provide them with the necessary tools for discussing sexual health with patients.

This article is protected by copyright. All rights reserved. 


\section{Introduction}

Sexuality is a multifaceted phenomenon and research is not confined to one particular field (Lundberg 2010). Furthermore, sexuality is often not accurately described and many people equate sex with sexuality. This can have a devastating impact on how people's sexual health issues are perceived in society. It also reflects the predominant paradigm in the healthcare context in which medical needs are prioritised in comparison to human needs in which understanding is central (Edwards 2001). Today, sexual well-being and sexual problems are given low-priority in healthcare; furthermore, only a limited amount of research has been done on how nurses talk to patients about sexual health (Löfgren-Mårtenson 2013, Tillman \& Mark 2015). The results of this research show that many nurses feel uncomfortable when talking to patients about sexuality; to resolve this issue, adequate training is essential (Olsson et al. 2012, Saunamäki et al. 2009, Umran et al. 2014).

\section{Background}

The World Health Organisation, WHO (2000) claims that sexual health is not just the lack of disabilities or disease but that it requires a positive and respectful approach towards sexuality and sexual relations. Sexual health is defined as a state of emotional, mental, physical and social wellbeing in relation to a person's sexuality. Sexual health is the possibility to have safe and enjoyable sexual experiences which are free from compulsion, violence and discrimination (WHO et al. 2000).

A number of illnesses including diabetes, vascular disease, cancer and depression affect sexuality in a negative way. Problems like lack of lust, sexual dysfunction, decreased or lack of erection, lubrication, ejaculation and orgasm are common (Hulter 2004, Kaplan 1979). Furthermore, many pharmaceuticals have a negative effect on sexual lust and ability (American Sexual Health Association 2015, Plantin \& Månsson 2012, Saunamäki et al. 2009). A large and intractable problem is lust and arousal difficulties that could be caused by biological or pharmaceutical conditions but also various diseases and health problems. Other possible factors could be anxiety, negative thoughts, stress, low self-esteem or physical or mental abuse. Problems with sexual lust may also be an effect of relationship difficulties, infidelity or religious or cultural standards which affect sexual desire. Furthermore, there are a number of sexually transmitted diseases which may cause pain for both women and men. Additionally, an unhealthy lifestyle can lead to low sexual libido (American Sexual Health Association 2015, Elmerstig 2012, Kaplan 1979). Today pharmacological aids such as Viagra, Cialis and Levitra have made it more acceptable to talk about erectile dysfunction in males (Katz 2007, Word Health Organisation 2010). In contrast, female sexuality is invisible in healthcare, especially regarding middle-aged women (Banister 2000). Research has shown that when compared to the situation in the 1970s, men and women aged between 70 and 79 have increased their sexual

This article is protected by copyright. All rights reserved. 
activity. Many elderly people continue to be sexually active despite serious and difficult physical diseases or limitations (Beckman et al. 2008, Buttaro et al. 2014, Marandola et al. 2004).

Sexuality is extremely complex as it refers to a core dimension of being human which includes multifactorial experiences of identity, love, eroticism and the capacity for reproduction, and therefore perhaps best understood using sociological frameworks of interpretation (Gagnon \& Simon 2005, WHO et al. 2000). Society's sexual values exist at different levels with the cultural and interpersonal levels described for the first time in the 1970s. Sexuality is not extraordinary in itself, meaning is created in the cultural environment Over the years, medical care in the Western world has constructed a common system of values developed from existing religious and societal norms and the medical paradigm which was formed during the 19th century (Lorentzen \& Ekenstam 2006, Plummer 2005). This system has shaped our standards of sexual behaviour and heteronormativity. It is based on the notion that all people are heterosexual and that men and women are expected to live in marriage. Sexuality under these conditions is more focused on reproduction than sexual liberation which, in the past and to this day, often mean less freedom for individuals that does not fit into existing sexual standards. This group consists not only of people belonging to the LGBTQ movement but also the elderly, disabled and ill people who are unable to adapt to the norm (Anderson 2012, Connell 2008, Gagnon \& Simon 2005). This norm in turn affects our ideal of hegemonic sexuality symbolised by the phallus. This generates power for those men whose identities still are based in traditional conceptions of gender. Unfortunately, however, this may also produce fear and insecurity among those who cannot live up to this ideal (Kimmel et al. 2005). Recent research shows that despite efforts to break up prevailing sexual norms, preconceptions of sexuality still exist (Anderson 2012, Sanchez et al. 2012). This becomes visible in organizations where these norms create barriers which reinforce existing asymmetrical conditions. This is particularly visible in marginalized groups but also manifests itself in the different healthcare professions (Bjorkman \& Malterud 2009, Gott et al. 2004).

Healthcare should have a holistic approach and within nursing communication, where non-verbal communication accounts for $70 \%$, is central (Bradley \& Edinberg 1986). Health professionals must become aware of their personal attitudes and the sexual norms that continue to prevail in the health sector. Otherwise individuals will continue to be and feel discriminated (Anderson 2012, Rasmusson et al. 2013). Healthcare personnel should be given training in how to discuss sexuality with all patients, i.e., the young, the elderly, immigrants, sexual-minority groups and indeed all minority groups. Research has shown that it is important for patients to know what happens to sexual lust and sexuality in disease and treatment. Sexual desire can also disappear without any health problems and regardless of the reason, the patient may need sexual counselling. Low libido issues

This article is protected by copyright. All rights reserved. 
are often overlooked in healthcare and the responsibility is left to the patient (Farrell \& Belza 2012, Rasmusson et al. 2013, Southard \& Keller 2009).

Studies from the areas of oncology and psychiatry show a lack of training in sexology. This makes it extremely difficult for nurses to bring up a subject which is important topic (Olsson et al. 2012, Quinn \& Happell 2012). Preventive health services are primarily provided by the primary care organization and sexual health issues should be incorporated here. However, relevant research studies on sexual health in primary healthcare are lacking. The focus for this study is sexual health in the primary-care setting.

\section{Aim}

To illuminate nurses' experiences and opportunities to discuss sexual health with patients in primary healthcare.

\section{Methods}

\section{Design}

This qualitative study used semi-structured interviews to gather data about the nurses' experiences. The same questions were asked to all the informants and led to open-response opportunities where all the informants had a chance to speak their mind (Kvale 1996).

\section{Participants}

Operation managers in different primary-care facilities in the southern part of Sweden were contacted and asked if they wanted to participate in the study. Sixteen primary-care facilities were approached and six were chosen, based on geographical distribution, to be included in the study. After permission by the Operation Manager at each workplace, the nurses were contacted and at a work meeting verbally given information about the study. Thirteen nurses, aged 41 to 63 , were invited to participate of which nine agreed to take part in the study. Eight were female and one was male. A requirement was that the participants were registered nurses, currently working at a primary-care facility. All informants had received further education such as district-nurse education, midwifery education and diabetes-nurse education.

\section{Data collection}

The data were collected through semi-structured interviews by two researchers, were tape-recorded and transcribed verbatim. The interviews lasted 20-45 minutes, with an average of 30 minutes. A

This article is protected by copyright. All rights reserved. 
pilot interview was carried out to see if the prospective questions would generate answers that responded to the aim of the study. The pilot interview was then analysed before the following interviews were held. This demonstrated the strengths and weaknesses in the interview technique. The interview guide was constructed in accordance with Kvale (1996) and consisted of two openended questions to provide an opportunity for the informants to describe the most important dimension of sexual health. The opening question was: Can you describe an encounter were sexual health was discussed? The opening question was then followed by: How do you feel to talk about sexual health with your patients? The questions were formulated to give the informants freedom to talk about their experiences and feelings. The interviewer tried to be as open-minded as possible and asked open ended follow-up questions during the entire interview. The interviews took place in a separate room at the informants' work places.

\section{Data analysis}

Qualitative content analysis was chosen since it gave the research team an opportunity to analyse the interviews systematically and to compare them and abstract the content to the descriptive categories. When the transcriptions were completed, the interviews were read a second time in order to achieve a better understanding and to gain a sense of the whole. Units of meaning were created and condensed and those who corresponded to the aim of the study were chosen. The interviews were encoded by content and paired together based on similarities and differences. They were then organized in different contents areas (Graneheim \& Lundman 2004).The content areas became subcategories during the analysing process where there was an intensive collaboration between all the researchers. Examples of the inductive analysis process are presented in Table 1. The ambition was to avoid interpreting the researchers' own understanding of the material. The transparency of the content analysis method contributes to establishing trustworthiness and credibility for the study. Quotations are used to illustrate the findings and increase the validity (Graneheim \& Lundman 2004).

\section{Ethical considerations}

All informants received information about the aim of the study both orally and in writing. In accordance with the Declaration of Helsinki, the informants were informed about their taking part being voluntary, the option to withdraw at any time without explanation, and their right to be anonymous (World Medical Association 2008). The informants were assured that the content of the interviews would be confidential during the whole process. According to Swedish law, ethical

This article is protected by copyright. All rights reserved. 
approval is not required for research studies conducted during advanced educational programmes; however, this was nevertheless applied for and granted. (Swedish Code of Statutes 2003/2008).

\section{Results}

The results are presented in two main categories: Factors that influence nurses' opportunities of talking to patients about sexual health and Nurses' experiences of talking to patients about sexual health. In each main category, subcategories were formed to illuminate the different subareas in each main category (Table 2 ).

\section{Factors that influence nurses' opportunities of talking to patients about sexual health}

Much of the nurses' work concerning patients' sexual health is governed by the care providing organizations and medical tradition. Lack of time and education as well as obligations and regulations in the nursing profession made it difficult to talk about sexual health. Structural flaws in the primary care organization were also a major obstacle for the nurses. Some of the nurses blamed the primary care organization while others found ways to work around this and provide good sexual healthcare despite lacking support from their organization.

\section{Varied education levels about sexuality as a subject}

All nurses in the study said that they wanted more education and knowledge about sexual health. None of the informants had any general education in sexology in their basic education or further education at their workplace which made them doubt their capability in the subject. The informants experienced that sexuality as a subject often was neglected in primary care even though all the informants had encountered the topic of sexual health in their work. The informants did not feel that the employer raised the issue of their need for education. Most of the informants were uncertain about how to respond to patients' questions about sexual health, if it did not concern potency or sexually transmitted diseases. The lack of knowledge and an unsupportive organization reduced the nurse's ability to accomplish the holistic care that is the primary focus of the nursing profession.

"It's all about time and resources and things like that actually. I think it is so when a doctor prescribes blood pressure medication, it is not even certain that he/she thinks about it. I believe that it is so that it's not that often you touch it or think about it [sexuality] (I1)

This article is protected by copyright. All rights reserved. 
One exception was in the area of diabetes where nurses felt they had adequate education about men's potency issues, although not on the matter of sexual health as a whole. This made them afraid to ask about other sexual health issues resulting in an incomplete understanding of the patient's needs.

“... and you can't ask questions about more than you can answer or have knowledge about." (I 8)

Some of the informants had found ways to work around this obstacle. They used a care-counselling support online which made them feel more secure. Some had a personal interest in this, and because of this, more knowledge which made them actively look for more information. Problems related to sexual health that the informants had experienced themselves also contributed to a higher level of knowledge in that area, information which they shared with their patients.

"Regarding physical problems, there are various lubricants to make the mucous membrane softer /// and because I'm a woman myself, after menopause when you get that kind of problems - I'm a little interested when something new comes out and want to be updated and so I can recommend it." (I 5) Competence in the primary-care workplace was created in different ways. Traditionally, much of the available of knowledge was transferred from pharmaceutical companies. Knowledge about male potency problems was thus increased, but information about pharmaceuticals to help women with dry mucous membranes was less often given. The lectures were very valuable for the nurses' knowledge and preparedness to meet patients' needs of sexual health advice. However, in the past five years briefings by pharmaceutical companies have been restricted as they are aimed at increasing sales of specific products which has resulted in decreasing knowledge in this area.

\section{The impact of health organizations on nurses' attitudes towards sexual health}

According to the nurses, the primary care organization did not present enough goals and guidelines regulating their work with sexual health. Regarding the subject of sexuality, only patients with diabetes and evidence of sexually transmitted diseases were in focus. The informants who had an interest here found ways to work with sexuality issues, but they experienced this as stressful as it required more time with the patient. This led to patients receiving different care depending on which nurse they met. Some of the nurses stepped back and focused on the medical problems instead of taking a holistic view.

This article is protected by copyright. All rights reserved. 
“...we are so pressed for time today, so you don't have the time. One does not see the whole person in that way, one sees a knee or a wound." (I 7)

There were also questions about whether sexual health was a part of healthcare and if the informants really had the right to talk about it. If the sexual health issues were vague or had an emotional aspect, the informants felt it was not their duty to talk about it. They often re-directed patients to doctors or midwives. This led to the situation where they did not know if the patients had received the help they requested due to clinics rarely collaborating. The nurses also claimed that primary care was not profiled as the setting where patients could present sexual health issues. One informant reflected on why healthcare does not promote sexual health. She wondered why it was not advertised at the primary health centre that it is possible to seek care for sexual problems while at the same time advertising about other conditions for which a patient may be looking for help.

\section{Nurses' experiences of talking to patients about sexual health}

When asked how it felt to talk with patients about sexual health, many nurses claimed that it felt natural. The interviews revealed that nurses thought it was easier to talk about erection issues with male patients with Type 2 Diabetes Mellitus. Other conversations about sexual health were seen as more difficult and the patients in these cases where referred to other care units. The nurses felt most uncomfortable talking to older patients, especially those over 80 years of age, patients who were not married and those with multiple illnesses.

\section{Gender differences affected the conversation about sexual health}

The nurses claimed that it was easier to talk to men about sexual health issues. The nurses explained that sexual health for men was treated as strictly physical and that they had a medical remedy which facilitated talking about sexual health. Female sexuality was different, more invisible. Although the nurses knew that women also experienced negative side effects from diseases like Type 2 Diabetes Mellitus, they did not raise the topic of sexual health with them.

Women's sexual health issues were described in terms of relationship problems and not as physiological problems which contributed to nurses not asking about it. They did not consider it to be their duty to talk to patients about relationship and psychological problems. The only sexual problem that female patients did talk about was fragile mucous membranes. The patients were often given the advice to buy oestrogen gel at the pharmacy or use a lubricant during intercourse. Male patients' sexual health was a subject that the nurses attended to if the patients were diabetic and the nurses claimed to have good knowledge about the impact of diabetes on erectile function.

This article is protected by copyright. All rights reserved. 
They also claimed to have good knowledge of how to treat this. Sexual health and diabetes was a regular subject that occurred on in-service training occasions which are held regularly at primary health care centres.

"They [women] can of course also get reduced sensitivity, because it has a lot to do with circulation and such to make the blood vessels become damaged, the small blood vessels, and it is clearly affecting the mucous membranes and experiences, like of orgasm, and otherwise it is of course some effect but I think the men might have a more difficult situation. Well so it is well that they notice it more for they have of course difficulties in completing sexual intercourse then if you cannot get an erection, it is the more difficult for them. Then maybe the experience for the woman ... we actually rarely talk to women about it." (I 5)

\section{The impact of age differences on the conversation}

The informants experienced a difference in how comfortable they felt talking about sexuality with patients due to a patient's age. The informants found it easier to talk to patients who were younger than themselves because they put themselves in a parental role. The nurses also experienced that younger patients were more outspoken about their sexual health. They found it difficult to talk to patients their own age although it was even more difficult to talk to patients who were over 80 years old. A majority of the nurses did not ask older patients about sexuality and they claimed that they did not think older patients had sex. After some consideration, a number of nurses changed their minds and said that it would be normal if older patients had sex and that it was their preconceptions that made them not ask.

“... yeah I haven't thought about it, I have not thought about maybe they're 80 years old and then you perhaps have some preconceptions that old people do not have sex, I'm sure it's so (laughs)." (16)

\section{Positive and negative experiences in conjunction with conversations with patients about sexuality} The nurses in primary healthcare had both positive and negative experiences in connection with sexual issues. Independently of this, the results show that nurses thought that sexuality, sexual health and sexual problems were something natural and should be taken seriously since they affected the patients' quality of life. The nurses claimed that it was important not to judge, to have an open mind and not criticize or moralize. They said that if they did not know how to help the patients, they could always listen and show that they took the patients' problems seriously.

This article is protected by copyright. All rights reserved. 
".... It should not be difficult for the patient, they should not be ashamed but we have to train ourselves so we feel safe in this because you can project this onto the patient so they feel secure when talking about sexual health." (I 6)

The informants who had positive experiences became braver and they invited more patients to conversations about sexual health. They meant that it was important to dare to ask and that it was their responsibility to make the patients feel comfortable in bringing up the subject. The nurses wanted conversations about sexuality to be as natural as possible. This led to them forming techniques which made this easier. For example, the nurses said that those were questions that they asked everybody in order for the patients not to feel uncomfortable. They could talk about possible side effects and then ask if the patients had noticed any of those. If the patients did not want to talk about these problems at the moment, the nurses anyway felt that they had opened up the subject and if the patients experienced problems they found it easier to bring them up. The nurses described this as "sensing the atmosphere". Time was an aspect as well and if the nurses did not have enough time for discussing sexual issues, they chose not to mention the subject at that time.

"Often, these issues are relevant only when the patient feels that it is a good time for it. That you are not too stressed and ask the patient: How are you? Is there anything you want to bring up?" (I 4)

The nurses in primary care also had negative experiences from talking to patients about sexual health including occasions where they even felt uncomfortable. They felt that the patients revealed too much or too private matters that did not have a place in healthcare. Negative experiences could also be experiences of sexual harassment or intrusive behaviour which led to fear of asking about sexual health.

"Maybe I was not expecting that he would go so much into detail as he did. He is married to a former colleague of mine and it was too much for me to hear that their sex life was not working and he was watching sex movies at night and masturbated and I just felt hey ... this was not what I asked. I felt uncomfortable."(I 7$)$

Another task that could be perceived as difficult was questions about sexually transmitted diseases. In some organisations, this was routine when people seek for urinary problems. Asking these questions to old people made the nurses feel that they sometimes violated the patients' privacy. This inhibited the nurses in their approach to these issues.

This article is protected by copyright. All rights reserved. 


\section{Discussion}

The construction of sexuality with the ideal of heteronormativity in modern Western societies, even in a progressive country such as Sweden, is still dominant today. Therefore, people seeking care for sexual health issues can, in some cases, feel discriminated against and nurses who are interested in sexual health issues are facing an uphill struggle. Notwithstanding that, the nurses demonstrate willingness and resolve to have increase understanding of sexual health and its impact on the human identity in today's primary healthcare. This could be a consequence of the patient-focused paradigm that is taking place in healthcare. Focus is now more on the patient's individual needs and requests (Ekman et al. 2011). For the nurses to be more secure in their professional capacity regarding sexual health, an organizational restructuring within primary care is necessary. Sexual health needs to be implemented and anchored in the care organization. This should take place in collaboration between the various occupational categories and the various health services. This is a major challenge because sexual health is such a complex phenomenon where meaning can vary depending on the situation and what significance it has in the unique situation. The difficulty is that the situation is perceived differently and when meeting with the patient, the professionals have to suppress their own sexual prejudices. (Anderson 2012, Gagnon \& Simon 2005, Rasmusson et al. 2013).

Organization structures impact nurses' possibilities and limitations. The nurses felt they needed time, a relationship with the patient, and knowledge and experience for conversations to be of good quality. They also describe sexuality as a less important subject as compared to medical problems. This could be the reason for the uncertainties about what the responsibility of healthcare should be. Should healthcare deal with patients' sexual problems? Should the medical tradition keep its focus on erection problems and sexually transmitted diseases? (Bungay et al. 2014, Löfgren-Mårtenson 2013). These questions reflect the nurses' professional insecurities. They feel as if there is no strong standpoint in healthcare on the subject of sexual health. According to the Public Health Agency of Sweden (2015), safe and secure sex is crucial for human well-being and should therefore be a part of healthcare. The nursing discipline is a relatively new discipline in Sweden and still, almost after four decades, nursing is subordinated medical science in some contexts (Acker 2006). This is probably one of many reasons why the patients' unique needs rarely are addressed within healthcare. For sexuality to have a distinct place within healthcare, a paradigm shift needs to take place to gives the nurses the opportunity to develop in their profession (Dahlberg \& Segesten 2010, Todres et al. 2007).

The informants made a difference between male and female sexuality. Many of the nurses claimed that sexual problems were more difficult for men than for women. This argument is based

This article is protected by copyright. All rights reserved. 
on the notion that a man's identity is closely connected to his erectile function. It is a positive thing that the nurses pay attention to men's sexual problems in primary care. This can be linked to potency pharmaceuticals, the existence of which make it easier to talk about erection problems (Elmerstig 2012, Elmerstig et al. 2012). Unfortunately, one can discern the consequences of stereotypical gender roles and expectations based on the discourse that marginalize the elderly population and especially elderly women (Dahlborg-Lyckhage \& Pilhammar-Andersson 2015, Hinchlif \& Gott 2008, Tillman \& Mark 2015). Here, the pharmaceutical industry has a great responsibility and the fact that today it is more difficult for representatives of the industry to market arguments for their products, to the medical staff must be seen as positive. The social norms we all have to relate to are an obstacle for health professionals' opportunities to feel comfortable and be professional. Supporting staff with regular supervision, guidelines and training, can provide insights and be of help in order to implement a view critical of existing normative structures (Arvidsson et al. 2008).

The informants feared that the patients would feel that their privacy was violated if asked about sexuality. This made them abstain from asking because they did not want them to take offence. This attitude recurs in studies by Magnan et al (2005) who writes that nurses did not think patients expected nurses to talk to them about sexual health. However, other research shows that this is an unwarranted fear since patients have a need to talk about their sexuality and would feel comfortable doing so with a nurse (Farrell \& Belza 2012, Klaeson 2011, Southard \& Keller 2009).

The results show that the nurses did not want to know intimate and private details about patients' sexuality. When a question of a sexual character was asked, they only wanted an answer to that particular question. To ask patients about problems with erection was a natural question that the nurses found easy to handle since this problem has a medical answer. But if patients asked other questions or mentioned problems about their sexuality, the nurses found it harder to handle that. This is consistent with the result from the study by Gott et al (2004) where the staff experienced questions about sexuality as a "Pandora's box" which meant a risk to invite the patient to something they did not feel able to deal with in the context of their work. There was insecurity around what the responsibility of healthcare should be. This can probably also be traced to the nurses' selfconfidence and awareness of the complexity of sexuality (Anderson 2012, Gagnon \& Simon 2005).

Nurses in primary care in our study have limited knowledge about sexuality as a subject. None of the informants had had any education about sexuality in their primary basic education. Neither had they received any education or lectures about the subject at the workplace. The nurses claimed to have too little knowledge to feel secure on the subject. Previous research shows that nurses often have a low educational level when it comes to sexual education (Olsson et al. 2012, Quinn \& Happell

This article is protected by copyright. All rights reserved. 
2012, Saunamäki et al. 2009). In anticipation of the implementation of person-centred care, professionals would be helped with gender-sensitive approaches. By taking help from feminist theories, the professionals can get a common set of values to invite a dialogue about sexuality issues more frequently than is the case today (Miers 2002). In a study from Sweden, the researchers were able to determine that independently of gender, the existential dimensions had been negatively affected because patients' sexuality had not been made visible. Here you could also say that the male patients were particularly vulnerable because they could not live up to the social norms prevailing in the Western world (Klaeson 2011).

\section{Limitations}

It must be kept in mind that this is a small-scale study conducted in a small region in Sweden, which that in itself is of course a limitation. However on the other hand, the participants were experienced nurses eager to shed light on the subject of sexuality. The researchers have endeavoured to be as responsive and rigorous as possible in regard to the informants' narratives through the whole research process. Consequently in that way, the researchers aimed at trustworthiness a guarantee for validity in qualitative research (Kvale 1996).

\section{Conclusion}

This study shows that nurses in primary healthcare are facing an uphill struggle regarding sexual health issues. Fear, prejudice, personal beliefs and organizational design contribute to the nurses' feelings of uncertainty about bringing up the subject. This results in an absence of nursing. Lack of knowledge and practice in nurses' fundamental education can also be seen as a barrier to healthpromotion conversations about sexuality. The Swedish Higher Education Authority (UKÄ) needs to involve sexual nursing in their educational plans in order to make nurses feel more secure in themselves and gain self-esteem in their nursing profession (The Swedish Society of Nursing 2011). The study shows that nurses want to work more actively with sexual health. For this to occur, greater focus on sexual health on an organizational level and giving the nurses a chance to work with their profession, caring, will be required. The medical paradigm requires a change to focus more on nursing and patient-focused care. From the results of this study, we claim that more nursing research focusing on sexual health is needed in order to implement evidence-based care. This is

This article is protected by copyright. All rights reserved. 
necessary in order to challenge the normative structures regarding sexuality so that each patient will be treated according to their individual life-world.

\section{Relevance to clinical practice}

The findings of the study show that nurses find it important to talk about sexual health with their patients; however, because of the ideal of heteronormativity, they find it difficult. They request more education and training on the subject. The results may provide support for individual nurses or employers to implement training at the workplace to make health professionals more comfortable regarding sexuality issues. The findings may also increase awareness among healthcare professionals of the challenges of working with sexual health. The result further shows that women's problems with sexuality are overlooked and ignored. Therefore, gender studies and collaboration studies in the health professions are needed and must be implemented in the future. Further research on sexual health in primary healthcare which highlights the similarities and differences in how nurses are actively working with sexual health today is also important. People need help with their sexual problems and they expect healthcare professionals to have knowledge about this topic.

\section{Disclosure}

The authors have confirmed that all authors meet the ICMJE criteria for authorship credit (www.icmje.org/ethical 1 authors.html) as follows: (1) substantial contributions to conception and design of, or acquisition of data or analysis and interpretation of data, (2) drafting the article or revising it critically for important intellectual content and (3) final approval of the version to be published.

\section{Conflict of interest}

All authors declare no conflict of interest

\section{Funding}

No grants, funding or sources of support to be stated.

This article is protected by copyright. All rights reserved. 


\section{References}

Acker J (2006): Inequality Regimes Gender, Class, and Race in Organizations. Gender \& Society 20, 441-464.

American Sexual Health Association A (2015), http://www.ashasexualhealth.org/ (accessed 24 August 2015).

Anderson E (2012) Inclusive masculinity: the changing nature of masculinities. Routledge, New York.

Arvidsson B, Skärsäter I \& Öijervall J (2008): Process-oriented group supervision implemented during nursing education: nurses' comceptions 1 year after their nursing degree. Journal of Nursing Management 16, 868-875.

Banister EM (2000): Women's midlife confusion: "Why am I feeling this way?". Mental Health Nursing 21, 745-764.

Beckman N, Waern M, Gustavson D \& Skoog I (2008): Secular trends in self reported sexual activity and satisfaction in Swedish 70 Years old: cross sectional survey of four populations, 19712001. British Medical Journal 337, 151-163.

Bjorkman M \& Malterud K (2009): Lesbian women's experiences with health care: A qualitative study. Scandinavien Journal of Primary Health Care 27, 238-243.

Bradley JC \& Edinberg A (1986) Communication in the nursing context. Appleton-Century-Crofts, Norwalk, Conn.

Bungay V, Masaro CL \& Gilbert M (2014): Examining the scope of public health nursing practice in sexually transmitted infection prevention and management: what do nurses do? Journal of Clinical Nursing 23, 1365-2702.

Buttaro TM, Koeniger-Donohue R \& Hawkins J (2014): Sexuality and Quality of Life in Aging: Implications for Practice. Journal for Nurse Practitioners 10, 480-485.

Connell RW (2008) Maskuliniteter [Masculinities] (in Swedish). Daidalos, Göteborg.

Dahlberg K \& Segesten K (2010) Hälsa och vårdande: i teori och praxis [Health and care: in theory and practice] (in Swedish). Natur \& kultur, Stockholm.

Dahlborg-Lyckhage E \& Pilhammar-Andersson E (2015): Predominant Discourses in Swedish Nursing. Policy, Politics \& Nursing Practice 10, 163-171.

This article is protected by copyright. All rights reserved. 
Edwards SD (2001) Philosophy of nursing: an introduction. Palgrave, Basingstoke.

Ekman I, Swedberg K, Taft C, Lindseth A, Norberg A, Brink E, Carlsson J, Dahlin-Ivanoff S, Johansson IL, Kjellgren K, Lidén E, Öhlen, J, Olsson L-E, Rosén H, Rydmark M \& Stibrant Sunnerhagen K (2011): Person-centered care - Ready for prime time. European Journal of Cardiovascular Nursing 10, 248-251.

Elmerstig E (2012) Sexuella problem och sexuella dysfunktioner [Sexual problems and sexual dysfunctions] (In Swedish). Sexualitetsstudier [Sexuality studies] (In Swedish). (Plantin L \& Månsson S-A eds.).

Elmerstig E, Wijma B, Sandell K \& Berterö C (2012): "Sexual pleasure on equal terms": young women's ideal sexual situations. Journal of Psychosomatic Obstetrics \& Gynecology 33, 129134.

Farrell J \& Belza B (2012): Are Older Patients Comfortable Discussing Sexual Health With Nurses? Nursing Research 61, 51-57.

Gagnon JH \& Simon W (2005) Sexual conduct: the social sources of human sexuality. AldineTransaction, New Brunswick.

Gott M, Galena E, Hinchliff S \& Elford H (2004): "Opening a can of worms": GP and practice nurse barriers to talking abour sexual health in primary care. Familiy Practice 21, 528-536.

Graneheim UH \& Lundman B (2004): Qualitative content analysis in nursing research: Concepts, procedures and measures to achieve trustworthiness. Nurse Education Today 24, 105-112.

Hinchlif S \& Gott M (2008): Challenging Social Myths and Stereotypes of Women and Aging: heterosexual Women Talk About Sex. Journal of Women and Aging 20, 65-81.

Hulter B (2004) Sexualitet och hälsa: begränsningar och möjligheter[Sexuality and health: limitations and possibilities] (In Swedish). Studentlitteratur, Lund.

Kaplan HS (1979) Disorders of sexual desire. New York: Simon and Schuster.

Katz A (2007) Breaking the Silence on Cancer and Sexuality. A handbook of Healthcare Providers. ONS Publishing Division, Pittsburgh.

Kimmel MS, Hearn J \& Connell R (2005) Handbook of studies on men and masculinities. Sage Publications, Thousand Oaks, CA.

This article is protected by copyright. All rights reserved. 
Klaeson K (2011) Sexuality in the aftermath of breast and prostate cancer. Gendered experiences. Department of Medical and Health Sciences. Linköping, Linköping.

Kvale S (1996) InterViews An Introduction to Qualitative Research Interviewing. Sage, London. Lorentzen J \& Ekenstam C (2006) Män i Norden: manlighet och modernitet 1840-1940 [Men in the Nordic countries: virility and modernity 1840 - 1940] (in Swedish). Gidlund, Möklinta.

Lundberg P-O (2010) Vad är sexologi? [What is sexology?]. In Sexologi [Sexology] (In Swedish) (Lundberg P-O \& Löfgren-Mårtenson L eds.). Liber, Stockholm.

Löfgren-Mårtenson L (2013) Sexualitet [Sexuality] (in Swedish). Liber, Malmö.

Magnan MA, Renolds KE \& G GE (2005): Barriers to Adressing Patient Sexuality in Nursing Practice. Medsurg Nursing 14, 282-290.

Marandola P, Musitelli S, Noseda R, Stancati S, Vitetta D, Jallous H, Porru D, Zmerly H, Mensi M, Colombo P, Orlando G, Cebrelli T, Gerardini M, Giliberto G, Pasini L, Lillaz B, Pietropaolo F, Sali H \& Rovereto B (2004): Love and sexuality in aging. The Aging Male 5, 103-113.

Miers M (2002): Developing an understanding of gender sensitive care: exploring concepts and knowledge. Journal of Advanced Nursing 40, 69-77.

Olsson C, Berglund A-L, Larsson M \& Athlin E (2012): Patient's sexuality - A neglected area of cancer nursing? European Journal of Oncology Nursing 16, 426-431.

Plantin L \& Månsson S-A (2012) Sexualitetsstudier [Sexuality studies] (In Swedish) Liber, Stockholm.

Public Health Agency of Sweden (2015). Available at: http://www.folkhalsomyndigheten.se/aboutfolkhalsomyndigheten-the-public-health-agency-of-sweden/ (accessed 24August 2015).

Quinn C \& Happell B (2012): Talking About Sexuality With Consumers of mental Health. Perspectives in Psychatric Care 49, 13-20.

Rasmusson E-M, Plantin L \& Elmerstig E (2013): 'Did they think I would understand all that on my own?' A questionnaire study about sexuality with Swedish cancer patients. European Journal of Cancer Care 3, 361-369.

Sanchez DT, Fetterolf JC \& Rudman LA (2012): Eroticizing Inequality in the United Stated: The Consequences and Determinants of Traditional Gender Role Adherence in Intimate Relationships. Journal of Sex Research 49, 168-183.

This article is protected by copyright. All rights reserved. 
Saunamäki N, Andersson M \& Engström M (2009): Discussing sexuality with patients. nurses' attititudes and beliefs. Journal of Advanced Nursing 66, 1308-1316.

Southard NZ \& Keller J (2009): The Importance of Assessing Sexuality. Clinical Journal of Oncology Nursing 13, 213-217.

Swedish Code of Statutes (2003/2008) The Act Concerning the Ethical Review of Research Involving Humans (SFS 2003:460), http://www.epn.se/en/start/startpage/. Available at: http://www.epn.se/en/start/startpage/ (accessed 10 July 2015).

The Swedish Society of Nursing (2011) Foundation of Nursing Care Values. Available at: http://www.swenurse.se/in-english/publications-in-english/foundation-of-nursing-carevalues/ (accessed July 26, 2015).

Tillman JL \& Mark HD (2015): HIV and STI testing in older adults: an integrative review Journal of Clinical Nursing 24, 2074-2095

Todres L, Galvin K \& Dahlberg K (2007): Lifeworld-led healthcare: revisiting a humanising philosophy that integrates emerging trends. Medicine, Health Care, and Philosophy 10, 53-63.

Umran O, Gulbeyaz C \& Sukran B (2014): Discussing Sexuality with Cancer Patients: Oncology Nurses Attitudes and Views. Asian Pacific Journal of Cancer Prevention 15, 7321-7326.

WHO, PAHO \& WAS (2000) Promotion of Sexual Health: Recommendations for Action. Proceedings of a Regional Consultation convened by Pan American Health Organization (PAHO) \& World Health Organization (WHO) in collaboration with the World Association for Sexology (WAS) in Antigua, Guatemala, May 19-22, 2000. Available at: www.paho.org/english/hcp/hca/promotionsexualhealth.pdf (accessed March 30 2011).

Word Health Organisation (2010) Developing sexual health programmes. A framework for action.pdf (accessed March 30 2016).

World Medical Association (2008) WMA Declaration of Helsinki - Ethical principles for medical research involving human subjects. Available at: www.wma.net/en/30publications/10policies/b3/ (accessed October 12 2011).

This article is protected by copyright. All rights reserved. 
Table 1. Example of inductive text coding

\begin{tabular}{|c|c|c|c|c|}
\hline Informant quote & Condensed quote & Code & Sub-category & Category \\
\hline $\begin{array}{l}\text { "It's probably so } \\
\text { that in health } \\
\text { care we don't } \\
\text { like to talk } \\
\text { about things like } \\
\text { this because you } \\
\text { think it's not as } \\
\text { important as } \\
\text { other diseases. } \\
\text { Do you } \\
\text { understand what } \\
\text { I mean? Maybe } \\
\text { we don't think } \\
\text { about it." }\end{array}$ & $\begin{array}{l}\text { Health care } \\
\text { does not reflect } \\
\text { on sexuality as } \\
\text { an important } \\
\text { part of health }\end{array}$ & $\begin{array}{l}\text { The culture in the } \\
\text { health } \\
\text { organisations and } \\
\text { in society decides } \\
\text { what is okay to } \\
\text { talk about }\end{array}$ & $\begin{array}{l}\text { The impact of } \\
\text { health } \\
\text { organizations on } \\
\text { nurses' attitudes } \\
\text { towards sexual } \\
\text { health }\end{array}$ & $\begin{array}{l}\text { Factors that } \\
\text { influence } \\
\text { nurses' } \\
\text { opportunities of } \\
\text { talking to } \\
\text { patients about } \\
\text { sexual health }\end{array}$ \\
\hline $\begin{array}{l}\text { "...but the fact is } \\
\text { that it's more } \\
\text { obvious in men } \\
\text { because they } \\
\text { need to have an } \\
\text { erection and } \\
\text { women don't } \\
\text { need that in the } \\
\text { same way and } \\
\text { you know it's } \\
\text { not so often I } \\
\text { talk to women } \\
\text { about it." }\end{array}$ & $\begin{array}{l}\text { Nurses find } \\
\text { men's sexual } \\
\text { problems } \\
\text { palpable and } \\
\text { therefore it is } \\
\text { easier to talk to } \\
\text { men } \\
\text { Rarely speak to } \\
\text { women }\end{array}$ & $\begin{array}{l}\text { Nurses find } \\
\text { men's problems } \\
\text { more palpable. } \\
\text { Do not talk to } \\
\text { women }\end{array}$ & $\begin{array}{l}\text { Gender } \\
\text { differences } \\
\text { affected the } \\
\text { conversation } \\
\text { about sexual } \\
\text { health }\end{array}$ & $\begin{array}{l}\text { Nurses' } \\
\text { experiences of } \\
\text { talking to } \\
\text { patients about } \\
\text { sexual health }\end{array}$ \\
\hline
\end{tabular}

Table 2. Schematic report of the categories and sub-categories

\begin{tabular}{|l|l|}
\hline Category & Sub-category \\
\hline $\begin{array}{l}\text { Factors that influence nurses' opportunities } \\
\text { of talking to patients about sexual health }\end{array}$ & $\begin{array}{l}\text { Varied education levels about sexuality as a } \\
\text { subject }\end{array}$ \\
\hline $\begin{array}{l}\text { Nurses' experiences of talking to patients } \\
\text { about sexual health }\end{array}$ & $\begin{array}{l}\text { Gender differences affected the conversation } \\
\text { attitudes towards sexual health } \\
\text { about sexual health } \\
\text { The impact of age differences on the } \\
\text { conversation } \\
\text { Positive and negative experience in } \\
\text { conjunction with conversations with patients } \\
\text { about sexuality }\end{array}$ \\
\hline
\end{tabular}

This article is protected by copyright. All rights reserved. 